\title{
Managing Water for Tourism in the Phinda Private Nature Reserve, KwaZulu-Natal, South Africa
}

\author{
By Kevin F. Mearns* \\ Jacobus J. Grobler"
}

Tourism is heavily dependent on a consistent sustainable supply of good quality water for tourism. Water is used in the tourism industry for domestic purposes such as hygiene, food and drink preparation as well as recreational activities such as swimming, water sports and snow making (Gössling et al., 2012). Tourism in protected areas provides the opportunity for conservation initiatives to become financially viable this can however only be possible if a consistent supply of good quality water is readily available. Changing weather patterns and persistent drought conditions in many part of Southern Africa have necessitated the careful investigation of water as a critical resource for the sustainability of tourism. This study investigates the water sources and consumption rates of six tourism lodges located in the Phinda Private Game Reserve in KwaZulu-Natal, South Africa. The per capita consumption of water was also determined in order to provide benchmarks and guidelines for future water consumption and management. The potential of alternative water sources such as rainwater harvesting was also investigated. The loss in potential income from the lodges is also calculated in order to determine what the indirect cost would be if lodges would need to be closed as a result of water scarcity. These calculations provide management with a decision making mechanism should the closure of certain lodges be inevitable.

Keywords: rainwater harvesting, tourism, water consumption, water management.

\section{Introduction}

The tourism industry as a sector relies heavily on water. Water is needed for irrigation of gardens and golf courses, preparation of food and drinks, making snow for winter sports and general water activities such as swimming or motorised water sports (Gössling et al., 2012). Phinda Private Game Reserve (from here on referred to only as Phinda) is no different and relies largely on water for its survival. With game viewing as their main tourist attraction, both fauna and flora depend on water for their existence. Vegetation requires water to recover from grazing especially with bulk grazers such as elephant and buffalo on the property and animals need to drink water to prevent them dehydrating. Elephants can consume anything from $70 \mathrm{~L}$ to $190 \mathrm{~L}$ of water per day (Owen-Smith et al., 2006). It is also known that when tourism ventures are not managed properly, tourism activities can greatly contribute to water

\footnotetext{
* Professor, University of South Africa, Africa.

${ }^{\dagger}$ Graduate Student, University of South Africa, Africa.
} 
pollution and decrease water quality severely (Baoying \& Yuanqing, 2007). Improper management of sewage can lead to nutrient enrichments that damage ecosystems (Gössling, 2001) and can lead to an increase in blue-green algae in water. In certain countries, like Fiji and Sri Lanka, water use in tourism is more than eight times greater than that of the local community. This can lead to conflict and local uprisings should local communities be left with insufficient water supply in the future (Becken, 2014). Water is of utmost importance to Phinda as it is dependent on water for its existence, the livelihood of local communities and the survival of animals and ecosystems within its borders. It is therefore important that the resource is managed properly.

\section{Study Area}

Phinda belongs to \&Beyond, one of the world's leading adventure travel companies, designing personlised luxury safaris in 16 African countries. The company owns 33 lodges and employs more than 2000 people (\&Beyond, 2012). Phinda, meaning "the return" in Zulu, is situated in the northern parts of KwaZulu Natal between the N2 and R22. The reserve lies between the Isimangaliso Wetland Park to the North-East, Lake St Lucia to the South-East and the towns of Hluluwe to the South-West and Mkuze to the North-East (Figure 1). The reserve covers an area of 23,000 Hectares and has a subtropical climate. The region receives about $777 \mathrm{~mm}$ of rain per annum with most of the rainfall occurring during the summer months (October to April). Temperature ranges between $8^{\circ} \mathrm{C}$ to $23^{\circ} \mathrm{C}$ during the winter months (May to September) and between $24^{\circ} \mathrm{C}$ to $34^{\circ} \mathrm{C}$ during summer.

The reserve has seven distinct ecosystems with palm savannah and mountain bush to rare sand forest and dense thornveld (Bushscapes, 2015). The reserve also host Africa's famous Big 5 (Rhino, Lion, Elephant, Leopard and Buffalo) and 415 species of birds. Six lodges are within the reserve boundaries (Figure 2): Mountain Lodge which can accommodate 50 people in 25 chalets, Homestead and Zuka Lodge which each caters for eight people in four rooms, Forest Lodge which can accommodate 32 people in 16 units and Rock Lodge and Vlei Lodge which can each accommodate 12 people in six chalets. The water use at all six lodges were investigated during this study.

In 2007 \&Beyond signed a land-claim settlement with the local Makhasa and Mnqobokazi communities and returned 9,500 hectares of land to these communities. A lease agreement of 72 years was secured allowing \&Beyond to continue their operations (\&Beyond, 2011). 
Figure 1. Location of Phinda Private Nature Reserve in KwaZulu-Natal (Google Maps, 2015)

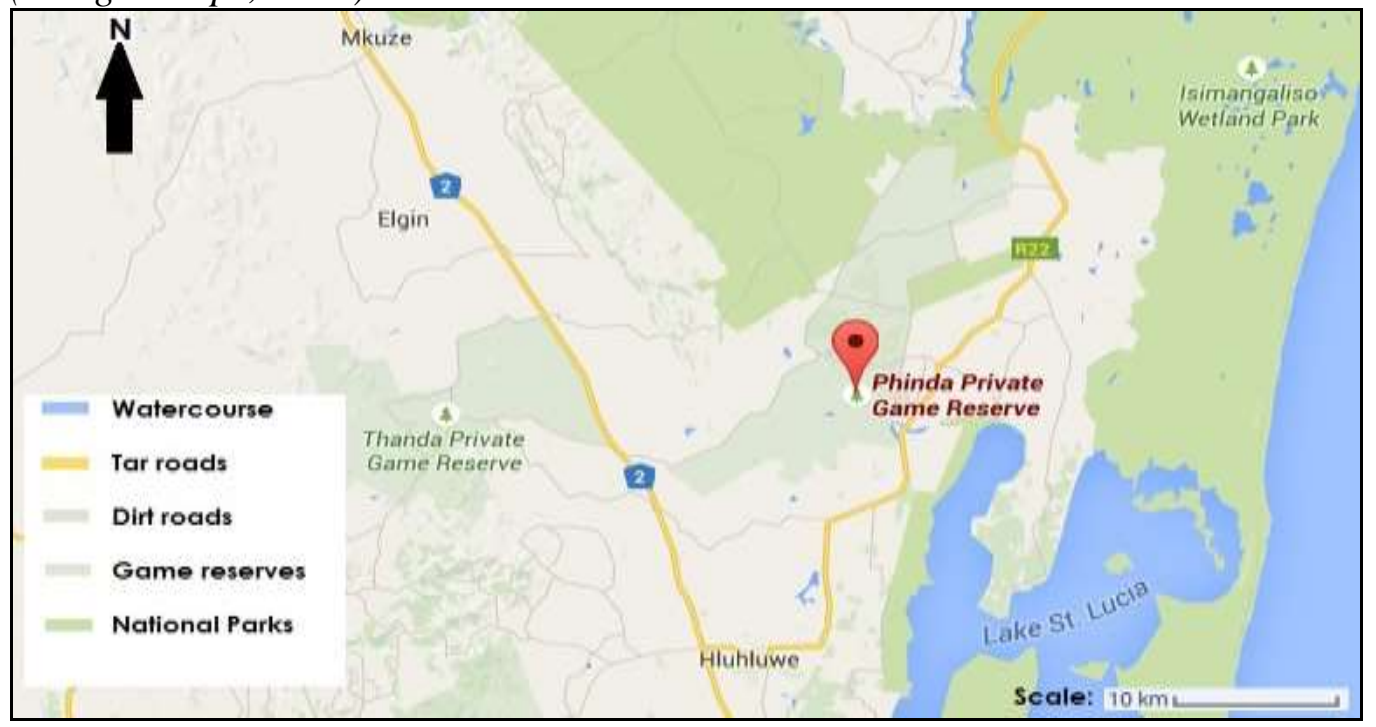

Figure 2. Location of Six lodges within the Phinda Private Nature Reserve

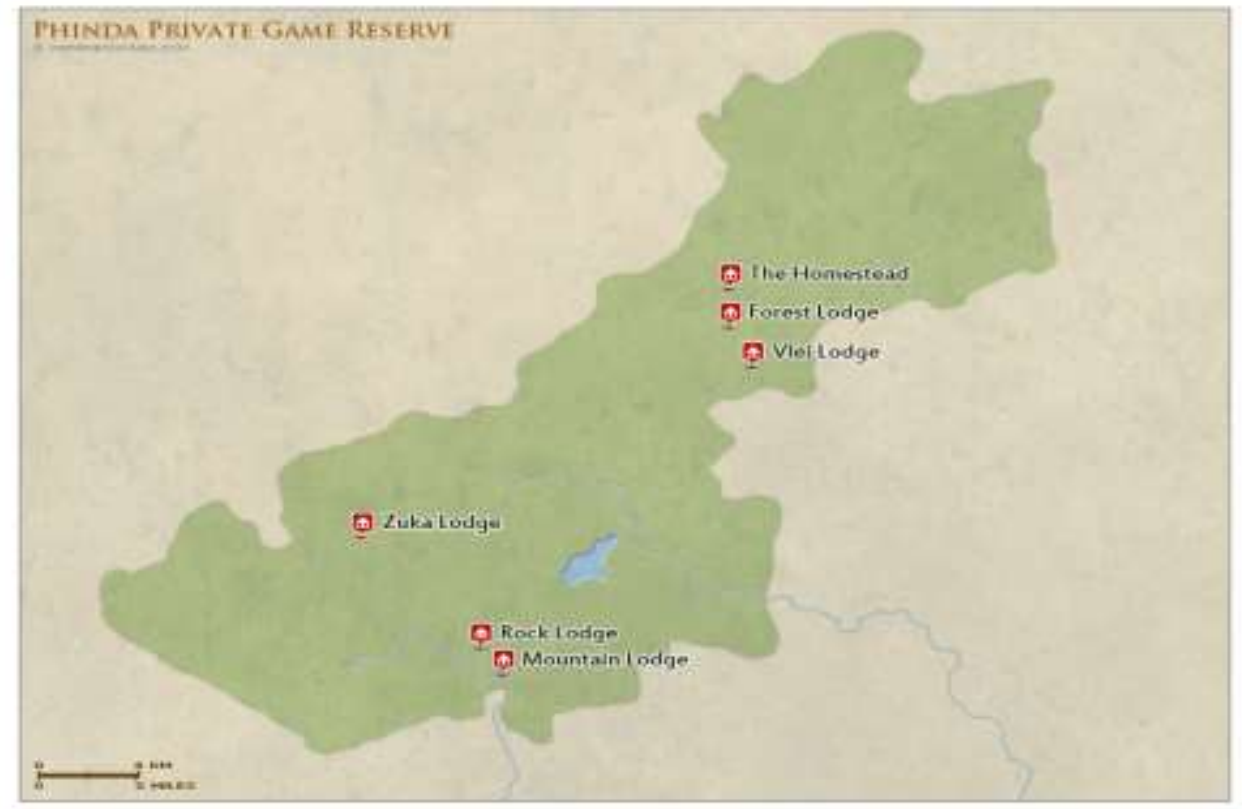

Research Problem and Questions

Tourism ventures around the world have negatively impacted on water resources due to poor management and contributed to the decline of freshwater supply. The tourism industry depends enormously on good quality freshwater for various activities and therefore, more often than not, uses more water than local communities. Water supply is critical to Phinda Private Nature Reserve as it needs water to sustain tourism activities as well as wildlife and ecosystem functioning. The management of freshwater is essential to the survival of the 
enterprise and the health of its clients. It is also critical for the management of Phinda to identify alternative resources to prevent conflict with local communities and use water as conservatively as possible without affecting its level of service. The following questions guide the research:

- What are the current water sources that supply each of the six lodges at Phinda?

- How much money in Rand is 1 litre of water worth to Phinda?

- How much water does a person use per night at each of the six lodges in the reserve?

- Does rainwater harvesting have potential as an alternative water source?

Research Objectives

The objectives of the research is to:

- Determine the present water sources at each of the six lodges.

- Establish the value of 1 litre of water to Phinda.

- Measure the amount of water a person per night consumes at each lodge.

- Investigate rainwater harvesting as an alternative water source.

The aim of this study was to determine the current sources, financial value, quantity of water use at each of the six lodges in Phinda and to evaluate alternative resources such as rainwater harvesting to supplement water supply to the lodges.

\section{Literature Review}

Freshwater supplies are becoming scarcer on a global scale mainly due to poor management and pollution. Proper management of water sources does not only play an important role in the supply of freshwater but also have a major effect on ecosystems and water quality if used unsustainably or mismanaged. In a study conducted by Gössling (2001) in Zanzibar, Tanzania to determine the effects of tourism for sustainable water use on a tropical island it was found that the region is water-poor and relies on freshwater harvesting from periodic rains that is stored in less efficient aquifers, which consist of freshwater lenses floating on the underlying seawater. The results showed that tourism-related groundwater abstraction on the east coast was beyond sustainable levels and signs of saltwater intrusion were observed. Sewage discharge in the near shore waters lead to nutrient enrichment which might contribute to changes in ecosystem composition and functioning. Due to the rise of tourist numbers to the island the demand for construction material increased which resulted in the destruction of mangroves, which in turn lead to an increase of erosion that 
deposits sediments on coral reefs and contributes to the degradation of this ecosystem (Gössling, 2001).

The tourism industry depends significantly on water as it is a resource that provides basic human needs such as hygiene and food, as well tourist activities. Gössling et al. (2012) released an article that reviewed the freshwater consumption in the tourism industry from a global view point. Literature studies and secondary data from 55 countries around the globe were analysed and interpreted to provide an average amount of water used per person per day $(\mathrm{p} / \mathrm{p} / \mathrm{d})$. The results provided in the article suggests that direct water use in the tourism industry varies between $80 \mathrm{~L}-2000 \mathrm{~L} \mathrm{p} / \mathrm{p} / \mathrm{d}$, with larger, resort-style hotels using between $2500 \mathrm{~L}-7500 \mathrm{~L}$ p/p/d (Gössling et al., 2012). Although the tourism sector only consumes $1 \%$ of global water, more often than not water usage in the tourism industry are higher than that of local communities. This can cause tension and uprisings, especially at Phinda which is surrounded by local, rural communities, should freshwater supply threaten the survival of these communities. Becken (2014) did a study to determine the contrast between tourism water use and that of the local community across 21 countries. Existing data was used to determine the contrast and the data was abstracted from AQUASTAT, a global information system on water and Earthcheck, an Australian benchmarking system with members over 70 countries that provide information on tourism water consumption. The results showed that in 12 of the countries that were analysed tourism water usage were more than double that of the local community. In seven countries the tourism water usage was slightly lower than that of the local community and in 2 countries the tourism water usage was slightly higher than that of the local community. In Fiji and Sri Lanka tourism water usage were 8.5 times more per person per night than that of the local community. Such imbalances could lead to water conflict situations and that tourism businesses must integrate their needs with local communities to obtain the best outcomes for businesses, tourists, communities and the environment (Becken, 2014). Since Phinda have close relations with local communities, such unrest can severely impact on their business as well as their corporate image and reputation.

To establish if Phinda's water usage is within acceptable levels, it had to be measured against performance indicators. Baker \& Mearns (2015) released an article that focussed on such indicators that relates to sustainable tourism and scarce water resources. These indicators were recognised as tools to assess and monitor sustainable development. The study was conducted at the Little Kulala Camp (LKC) in the Greater Namib-Naukluft National Park in Namibia. Borehole water, which is the main supply for the camp, were measured over a 28 month period from January 2010 and April 2012, and bottled water that was consumed during this period were added to the figure of borehole abstraction. The results were compared against a European standard known as the International Tourism Partnership (2008, p. 75). Compared to this standard, the results showed that the water usage at LKC was very high. The authors stated that this international standard is not suitable and applicable to tourism ventures in Southern Africa and other developed countries due to the fact that 
tourism establishment in these areas employ staff members that reside and work on the premises. The authors also stated that no benchmark or accepted baseline exist for Southern Africa. The results of this study by Baker \& Mearns (2015) will be used as a comparison against Phinda's water usage, as well as the International Tourism Partnership (2008, p. 75), although the latter will only serve as an indication of Southern African water use against European standards (Baker \& Mearns, 2015).

Rainwater harvesting is seen as a potential alternative source of water. Mwenga Kahinda \& Taigbenu (2011) investigated rainwater harvesting and the challenges associated with the process. Although their study focussed on rural communities and not the tourism industry, the same principles were applied to Phinda. The authors identified that more than 26,500 households in South Africa use rainwater as their main source of water. Rainwater was collected from rooftops, channelled and stored into water tanks where the water was tapped for domestic use. Mwenga Kahinda \& Taigbenu (2011) concluded that rainwater harvesting is a sufficient and effective alternative for supplying freshwater to rural communities although it should not be considered as the panacea for water supply. The potential of rain water harvesting at Phinda was investigated as a possible alternative.

\section{Research Design and Methods}

\section{Research Design}

This multiple case study investigated the current sources of water use at each of the six lodges independently. Secondary quantitative data was analysed and interpreted to answer the research questions and obtain answers to the research objectives. This exploratory study had an empirical design. The strengths of this design is that it is a form of applied research aimed at assessing whether interventions have well conceptualised and properly implemented. Some limitations of the design are access and coverage to the site and timing of the study. The mode of observation will be water quantity measurement and analysis of existing rainfall figures.

\section{Methods}

Water sources. An informal interview was conducted with Mr. Jonathan Braack, the group sustainability manager of \&Beyond, to determine the existing water sources of all six lodges. A predetermined set of questions were used to establish where water is sourced from as well as the processes involved before it is distributed to the lodges for usage and consumption. It became evident during the interview that all six lodges were served from two central points, one feeding the northern section of lodges and one feeding the southern sections of lodges. The two main lodges where water is distributed from were visited and an inspection was done on the water treatment facilities to gain a 
better understanding of the existing water sources and the processes that are currently implemented at Phinda.

Financial value of water. To determine the financial value of water the number of guest nights and rate per person per night were used to determine an estimate monthly income based on past figures (July 2014 to June 2015). The amount of revenue generated was then divided by the quantity of water to determine a value of Rand per litre of water. Since staff reside at the lodges, their water use was included in this study as staff form an integral part of the tourism venture. Insufficient data was available to establish exactly how much of the monthly water were used by guests and how much by staff. This calculation was made based solely on the total estimate income divided by the total quantity of water used. Further investigation will be required to establish accurate results.

Water quantity. Water meters were installed in the main supply pipelines of each of the six lodges. Meter readings were conducted at the end of each month and recorded as monthly usage. The usage of each lodge was calculated against the total usage of all six lodges to determine the percentage of water usage each lodge contributes to the total water usage at Phinda. The number of staff at each lodge was also calculated against the total number of staff from all six lodges to determine the percentage of staff that resides at each lodge.

The number of guests at each lodge and the number of staff that reside at the corresponding lodge per month were also collected. Only monthly figures were available and data was collected from July 2014 to June 2015 to calculate the average water used per person per night at each lodge. The results of the average daily use per person per night were split into two sets of results. The first considering both guests and staff, whereas the second set of results were linked to the international standard of only considering guests. These figures were also benchmarked against the findings of Baker \& Mearns (2015).

Rainwater harvesting. Rainfall figures were abstracted from a Davis Vantage Pro2 weather station that was installed at the reserve approximately four years ago. Only Forest lodge had sufficient roofing available to successfully harvest rainwater as the other lodges all have thatch roofs. All the appropriate roofs at Forest lodge were measured for length and width and added together to obtain an accurate area suitable for rainwater harvesting. According to Kinkade-Levario (2007), a maximum of $90 \%$ of rainfall can be harvested and the formula Area $\left(\mathrm{m}^{2}\right) \times$ Rainfall $\times 0.9=$ Total amount of litres, was used to make the estimate calculation. The calculations were made on a monthly basis.

\section{Discussion of Results}

\section{Water Supply}

Phinda can be divided into a northern section and a southern section. The lodges that forms part of the northern section are Forest, Homestead and Vlei 
Lodges. These three lodges get their water from the Mkuze river in the north of the reserve. Water is pumped from the river to a storage dam where water is stored for distribution to the water treatment facility sited Forest lodge. At Forest Lodge the water is stored in 10,000 litre tanks. The water is pumped from the tanks to the water treatment facility where it undergoes several filtration and flocculent treatments to purify the water. After treatment the water is again stored in 10,000 litre tanks for distribution to the three lodges. Figure 3 illustrates the water processes and distribution channels for the northern section.

Figure 3. Water Processes and Distribution in the Northern Section of Phinda

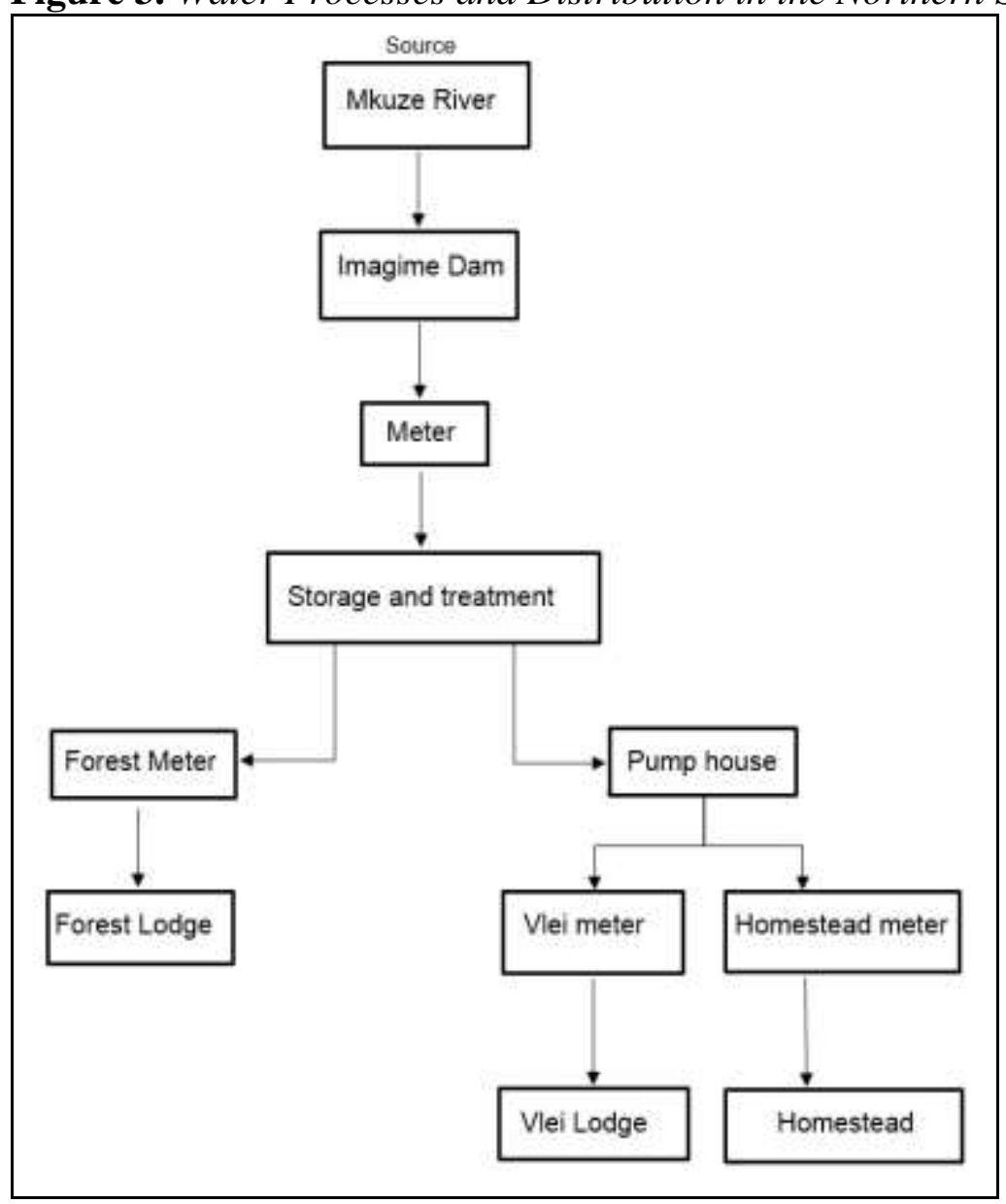

The lodges in the southern section namely, Mountain, Zuka and Rock Lodge, get their water from the Hluhluwe water scheme. Water from the scheme gets pumped into two large storage tanks from where it is transferred to a reservoir at Mountain Lodge. From the reservoir water is pumped through a filtration system and then to Mountain and Rock Lodge. The water that runs to Zuka Lodge does not go through the filtration system and is pumped directly from the municipal pipeline to the lodge. Figure 4 illustrates the water processes and distribution in the southern section of Phinda. 
Figure 4. Water Processes and Distribution in the Southern Section of Phinda

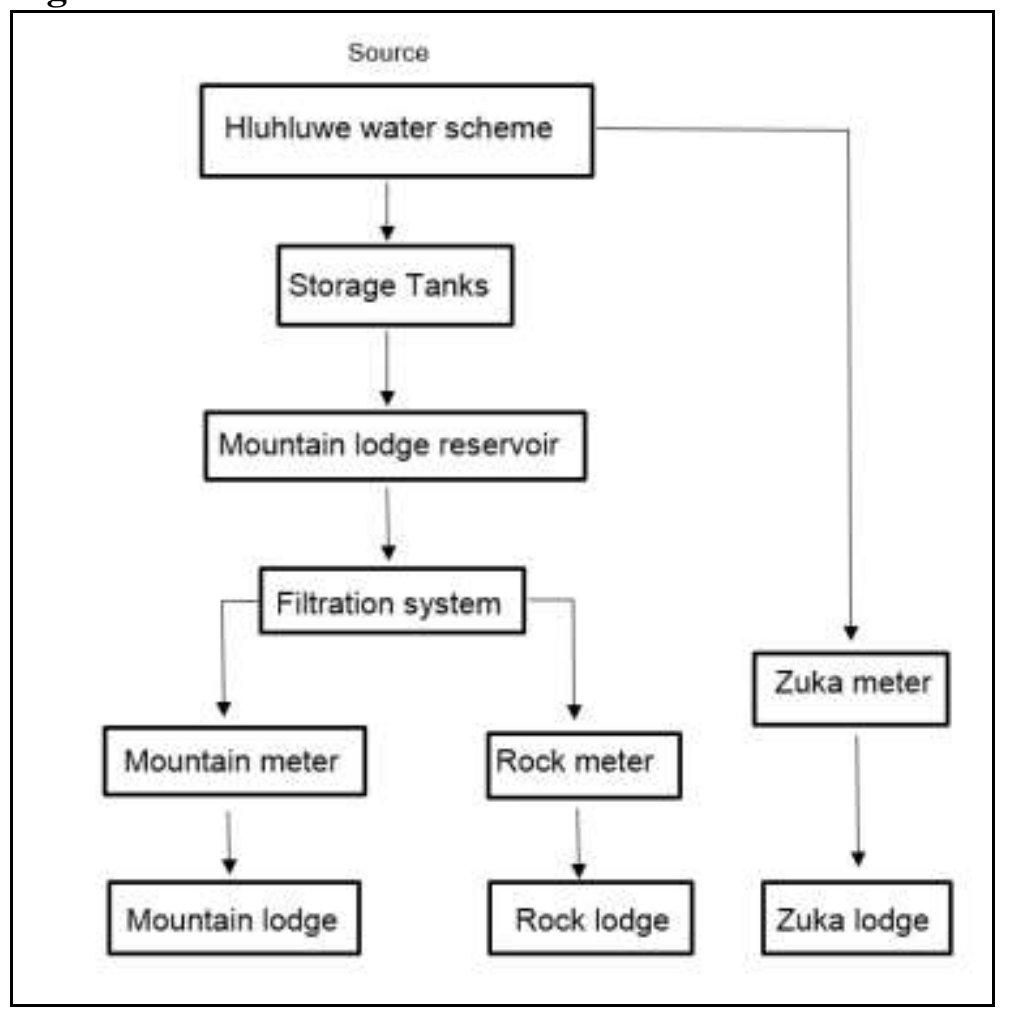

It was also stated during interviews with $\mathrm{Mr}$ Jonathan Braack that the northern section lodges run a greater risk of depleting their water source whereas the southern section has a more stable supply from the municipal pipeline from the Hluhluwe water scheme. It became evident that management will be forced to shut down lodges should the water supply in the north not be able to meet its demand, especially during the dry, winter season.

\section{Financial Value of Water}

Forest Lodge is the biggest lodge in the northern section and caters for 32 guests as mentioned previously. It also has a greater income than the other two lodges in the northern section (Vlei Lodge \& Homestead), and also consumes more water than these two combined. Although Forest Lodge generates the highest income of the three lodges, should water become scarce at the source it would be more viable to close Forest Lodge first rather than any of the other two. Forest Lodge consumes on average 1,533,667 litres of water, whereas Vlei Lodge and Homestead consumes on average 500,000 litres of water combined. This means that Vlei Lodge and Homestead can operate for three months on the same amount of water that Forest Lodge consumes in one month. Figure 5 illustrates the value in Rand that one litre of water generates for the three lodges in the northern section. An average for the whole of the northern section was also calculated to provide a more accurate figure as staff from Vlei Lodge and Homestead reside at Forest Lodge. This is most likely the 
reason that Vlei Lodge and Homestead shows a higher value for their water than Forest Lodge due to fact that the income generated by Vlei Lodge and Homestead are divided by a much lower consumption than Forest lodge.

The value of water at Vlei Lodge ranged between R5.56 and R11.50 per litre whereas the value at Homestead ranged between R3.27 and R7.67 per litre. Forest Lodge had the lowest value mainly due to the high number of staff that reside there and the value ranged between $\mathrm{R} 2.07$ and R4.28 per litre. It may be noted that the variation in value of water varies greatly as it is influenced by changing bed occupancies and associated services.

Figure 5. Value of Water in Rand per Litre in the Northern Section of Phinda

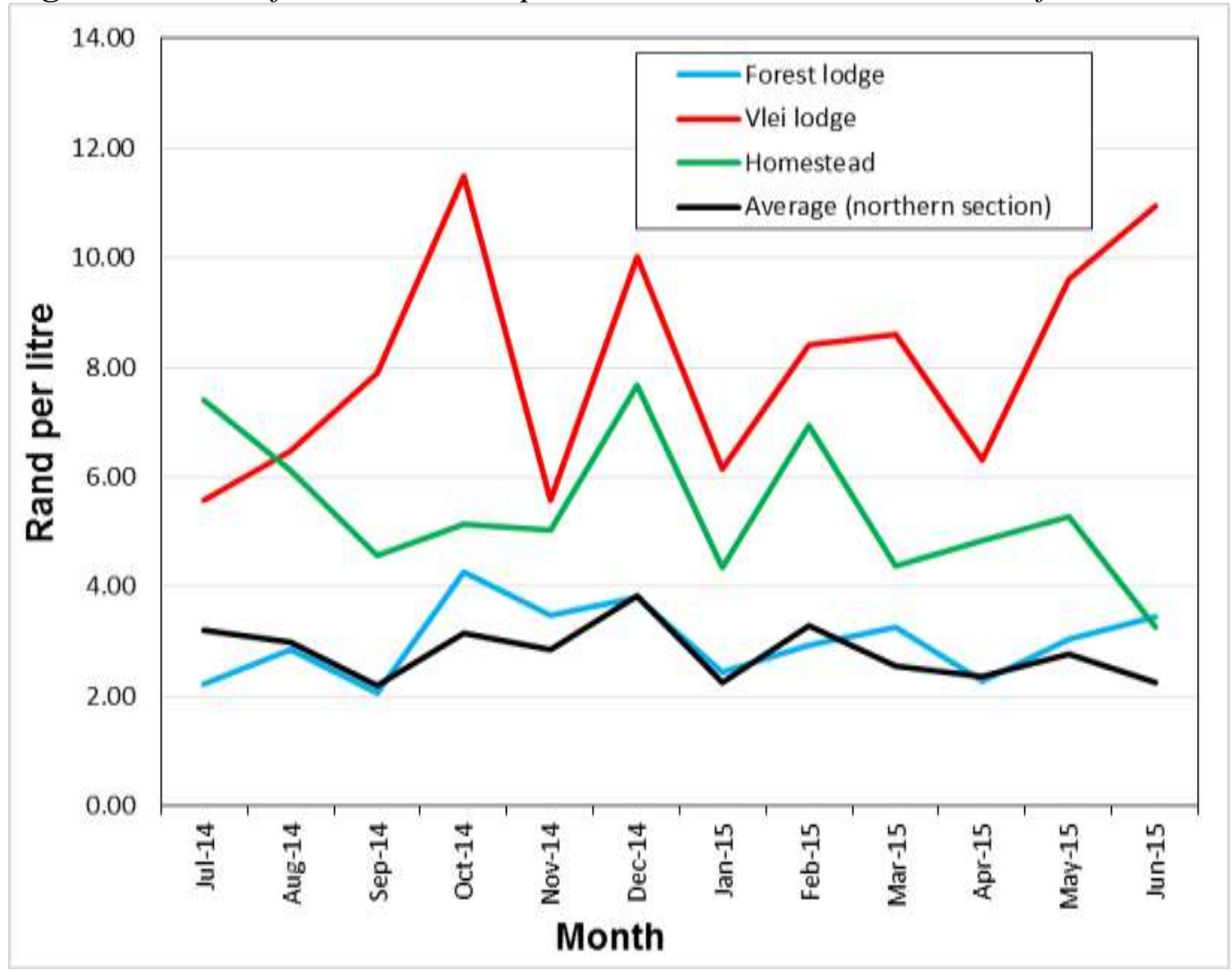

The average value for the northern section ranged between $\mathrm{R} 4.31$ and R7.16 per litre. The average value is the most accurate value at this stage and further investigation is required determine more accurate figures for the lodges due to the distribution of staff and the locations where they reside in the northern section.

\section{Water Quantity}

During the July 2014 and June 2015 period, the six lodges at Phinda consumed a total of 49,563,000 litres of water. Forest Lodge used the largest amount of water and was responsible for $37 \%$ of Phinda's water usage (Figure 6). Second was Mountain Lodge with $32 \%$ while Zuka and Rock Lodge both 
contributed only $9 \%$, Vlei Lodge and Homestead used $6 \%$ and $7 \%$ respectively and were the lowest consumers of all the lodges.

Figure 6. Percentage of Water Usage by the Six Lodges at Phinda

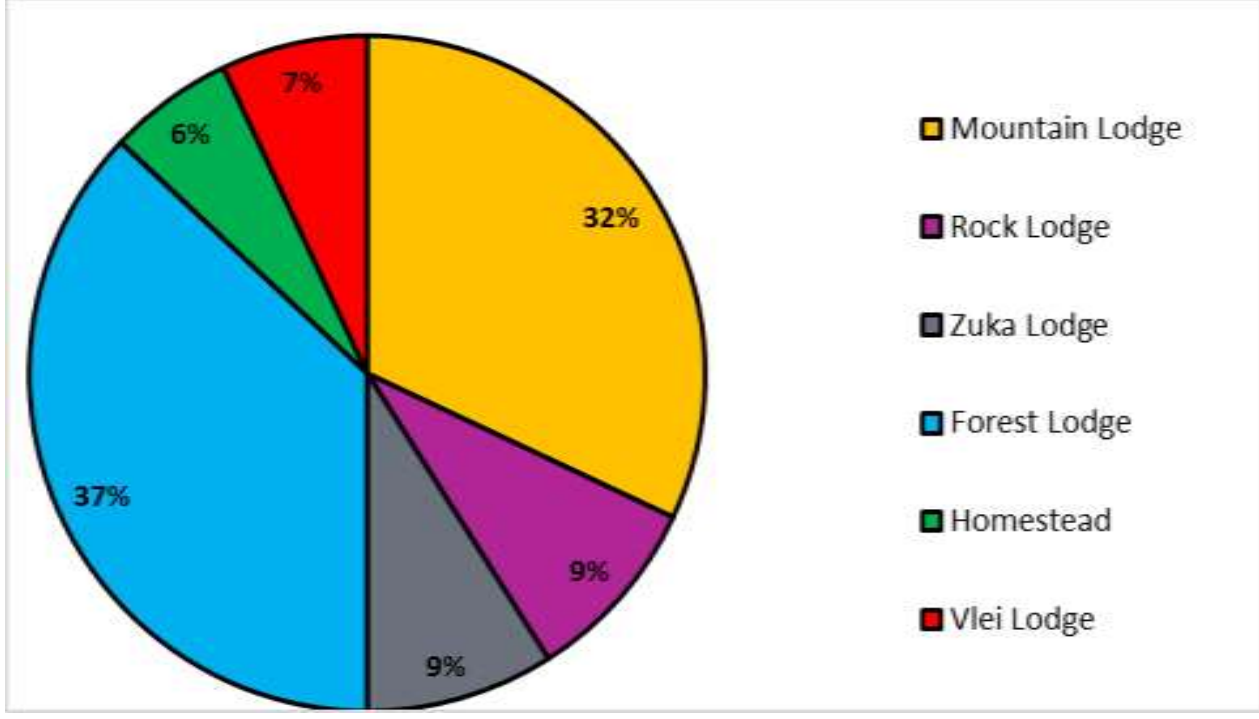

The water usage from Forest Lodge and Mountain Lodge is justified as these two lodges were responsible for $72 \%$ of all the bed nights at Phinda (Figure 7) during July 2014 and June 2015. Rock Lodge contributed only 4\% of the total bed nights whereas Zuka Lodge contributed 13\%, Vlei Lodge 5\% and Homestead $6 \%$.

Figure 7. Percentage of Bed Nights at the Six Lodges at Phinda

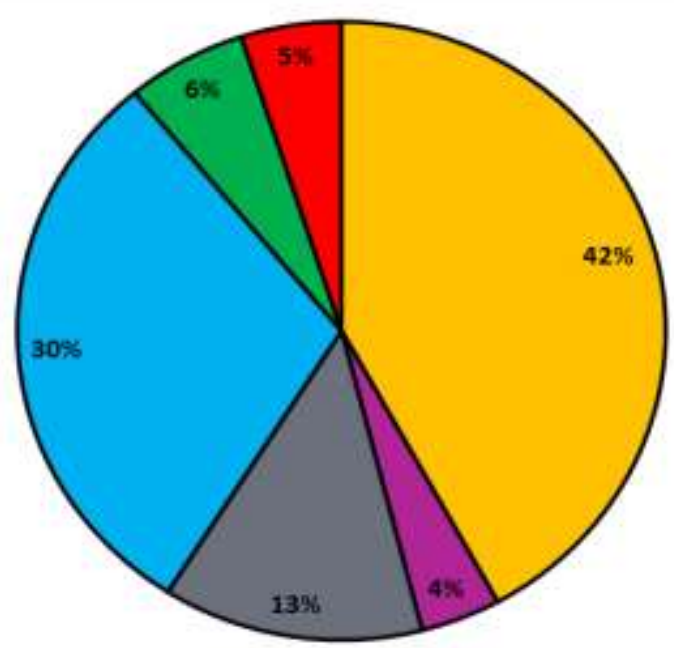

口Mountain Lodge

- Rock Lodge

口Zuka Lodge

口Forest Lodge

DHomestead

Vlei Lodge

Not only does Mountain Lodge have the highest number of bed nights, it also accommodates the highest number of staff with $43 \%$ (Figure 8 ). Forest Lodge accommodates the second highest number of staff with $31 \%$ whereas 
Zuka accommodates 17\%, Homestead 6\%, Vlei lodge 2\% and Rock Lodge only $1 \%$.

Figure 8. Percentage of Staff that Resides at the Six Lodges at Phinda

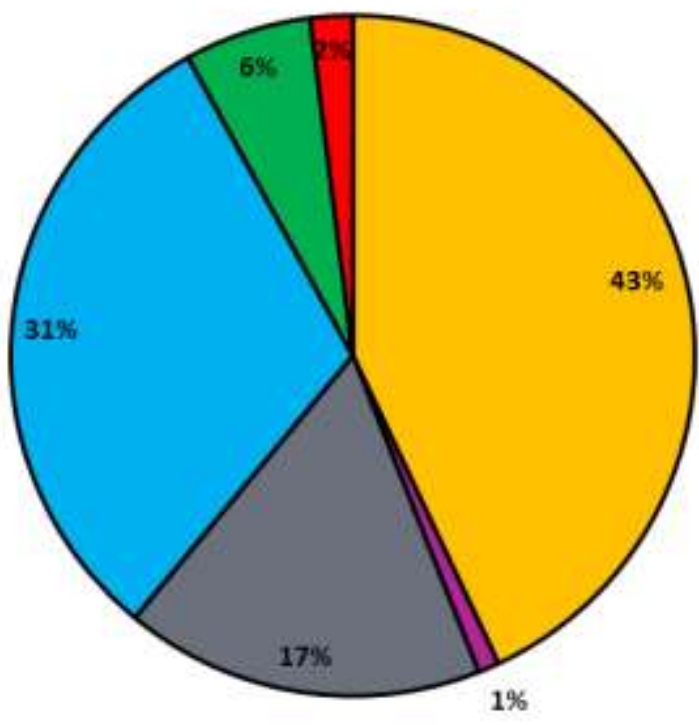

口Mountain lodge

- Rock lodge

口Zuka lodge

口Forest lodge

Homestead

viei lodge

In order to determine how much water is used per person per day, two different calculations were made. The first was to determine a general average considering the total water usage against the total number of bed nights (guests and staff). The second calculation used the total water usage against guests only. Although Forest and Mountain Lodge were the largest consumers of the total water at Phinda, they were not the highest per capita users of water. During the year under investigation, Rock Lodge consumed an average of 1,269 litres/person/day (Figure 9) whereas Forest Lodge consumed an average of 663 litres/person/day. Zuka Lodge had the lowest average with 391 litre/person/day while Mountain Lodge was second lowest with an average of 401 litre/person/day. Vlei Lodge was the second highest with an average of 684 litre/person/day. Homestead showed an average of 507 litre/person/day. 
Figure 9. Average Water Consumption Measured in Litre per Person per Day at the Six Lodges at Phinda from July 2014 to June 2015 (Guests and Staff).

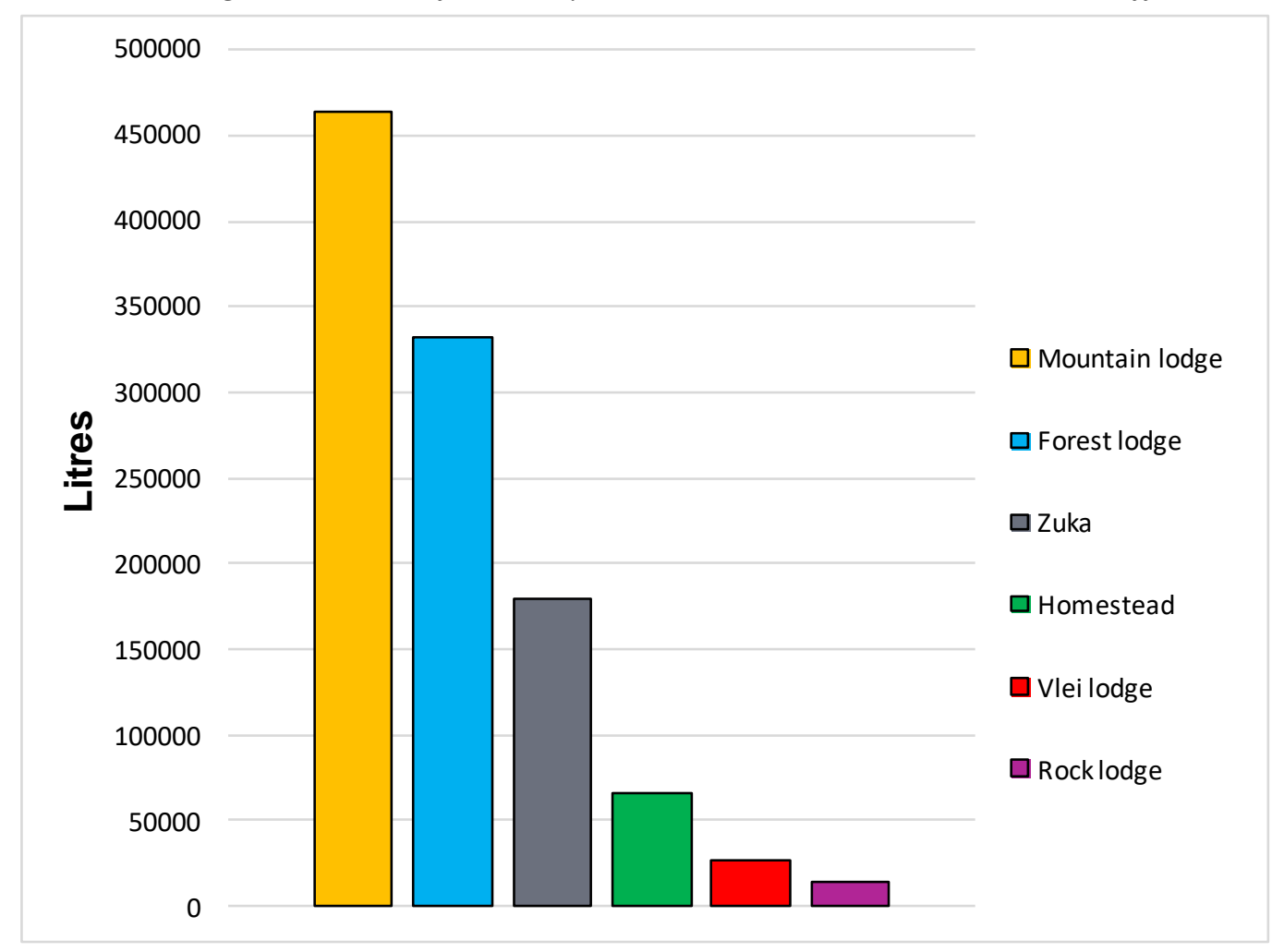

When staff nights were taken out of the equation a completely different picture emerged. The average water consumption per person per night considering guest nights only changed with Zuka Lodge being the highest consumer with an average of $2,623 \mathrm{l} / \mathrm{p} / \mathrm{d}$. Second was Forest Lodge with an average of 1,866 1/p/d. Rock Lodge came third with an average 1,667 1/p/d whereas Homestead was the fourth highest consumer with an average 1,399 $1 / \mathrm{p} / \mathrm{d}$. The two lowest consumers were Mountain Lodge with an average of 1 $194 \mathrm{l} / \mathrm{p} / \mathrm{d}$ and Vlei Lodge with an average of $940 \mathrm{l} / \mathrm{p} / \mathrm{d}$. The results are illustrated in Figure 10.

The results from the two calculations were measured against the International Tourism Partnership's (2008) guidelines to evaluate how water quantity at Phinda compares to water usage in other international tourism regions, mainly in Europe. The results indicated that water usage at Phinda was very high when compared to the international standard (Figure 11). Baker \& Mearns (2015) stated in their study that this standard can only be used as a guide to make comparisons and is not relevant to tourism ventures in developing countries and especially in Southern Africa, mainly due to staff living on the premises of tourism ventures. 
Figure 10. Average Water Consumption Measured in Litre per Person per day (Guests only)

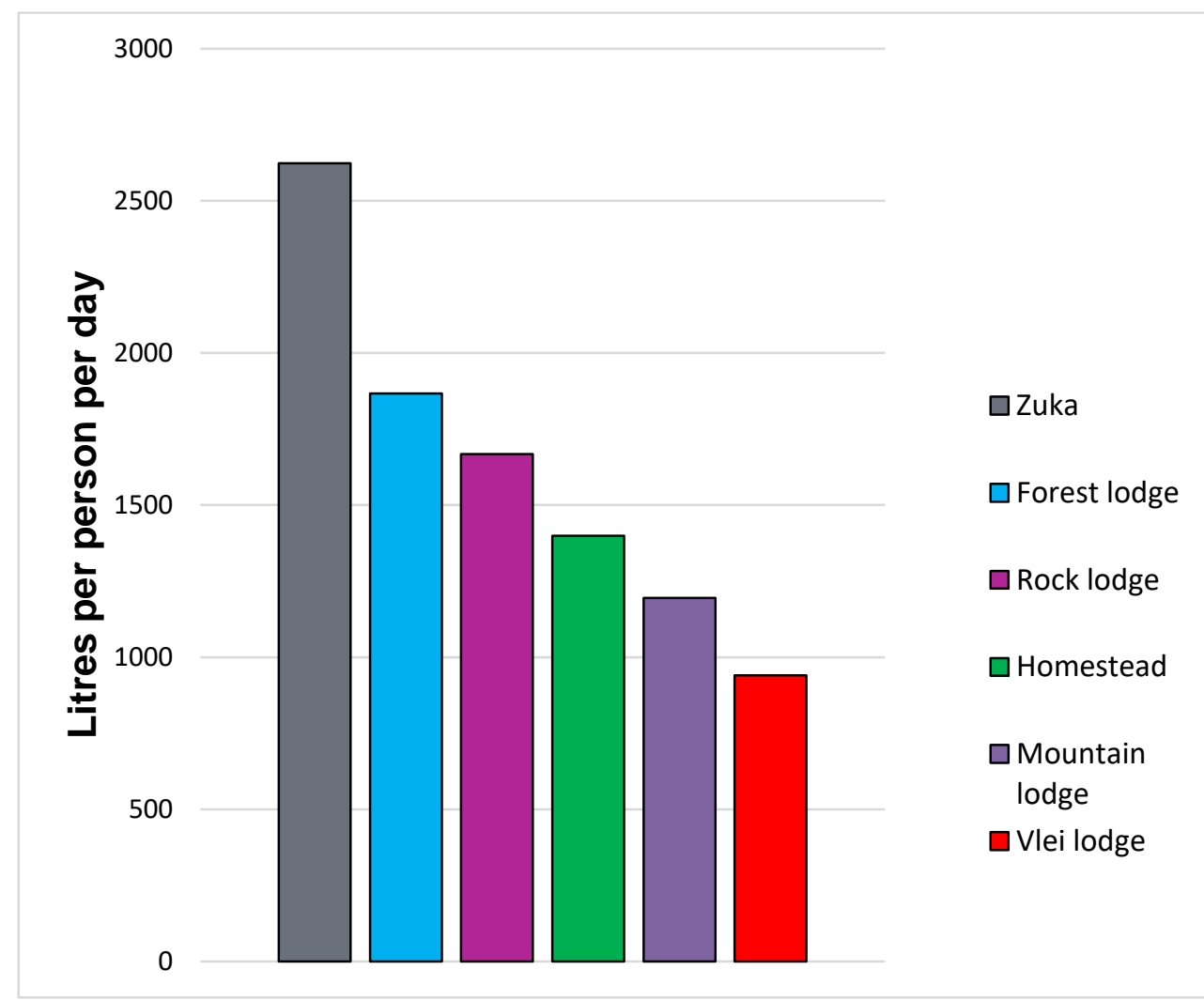

Figure 11. Water Usage of the Six Lodges at Phinda Compared to the International Tourism Partnership (2008) Guideline

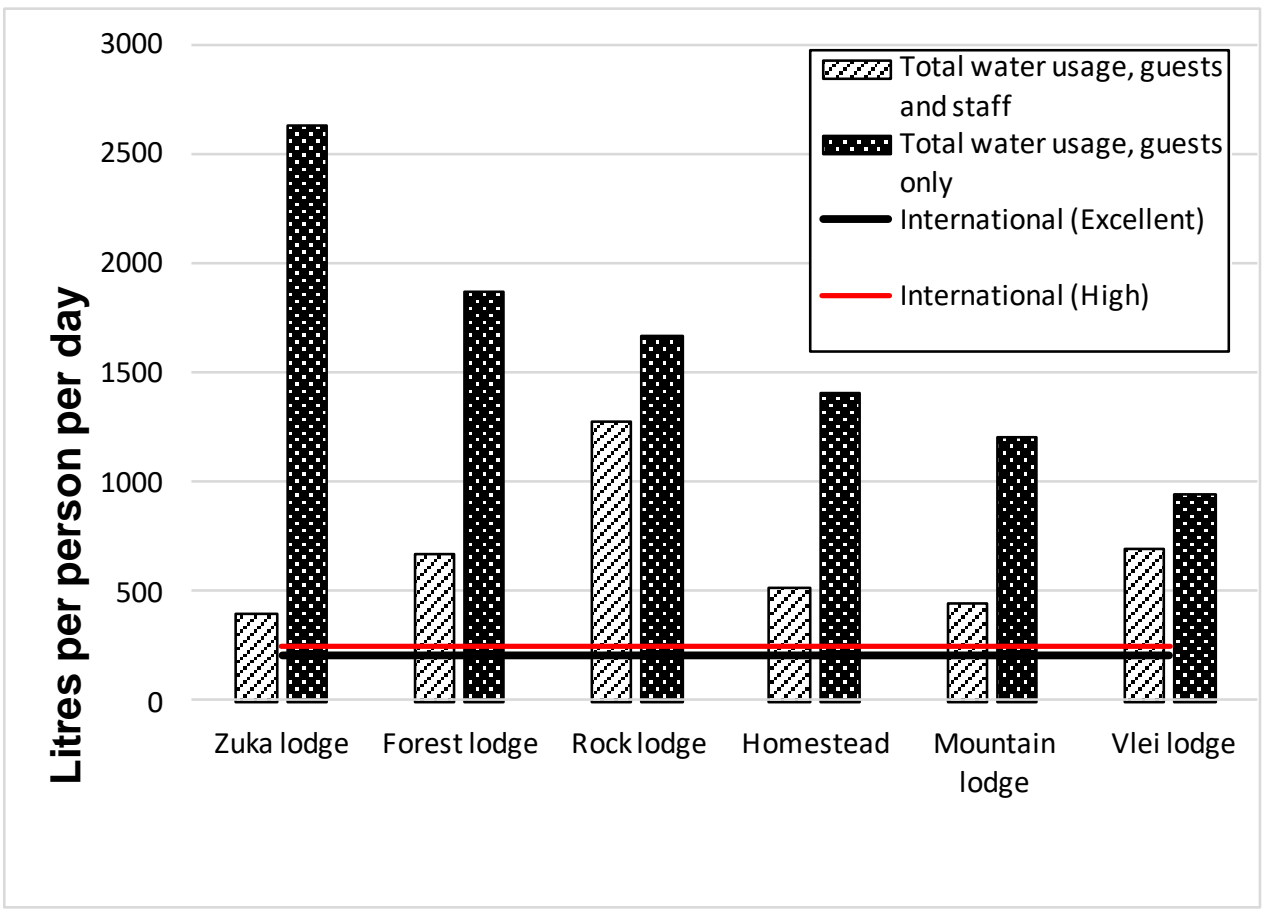


Although Forest Lodge is not the highest consumer of water per capita, it does consume the most water of all the lodges with an average of 1,533 667 litres of water per month. Mountain lodge, which is the biggest lodge in the southern section is the second largest consumer and uses on average 1,322,500 litres of water per month. Zuka Lodge and Rock uses on average 386,500 and 382,583 litres of water per month correspondingly whereas Vlei Lodge and Homestead are the lowest consumers with an average of 272,917 and 232,083 litres of water per month respectively (Figure 12). Staff distribution plays a major role in the amount of water that is consumed at the lodges and also impacts the usage per capita. Staff working at Vlei Lodge resides at Forest Lodge and the same applies for Rock Lodge staff that reside at Mountain Lodge. The distribution of staff does complicate the results and could be misleading at certain stages. Further investigation regarding staff usage and the role they play in water consumption at Phinda is required to provide more accurate details and results.

Figure 12. Average Water use per Month at the Six Lodges at Phinda

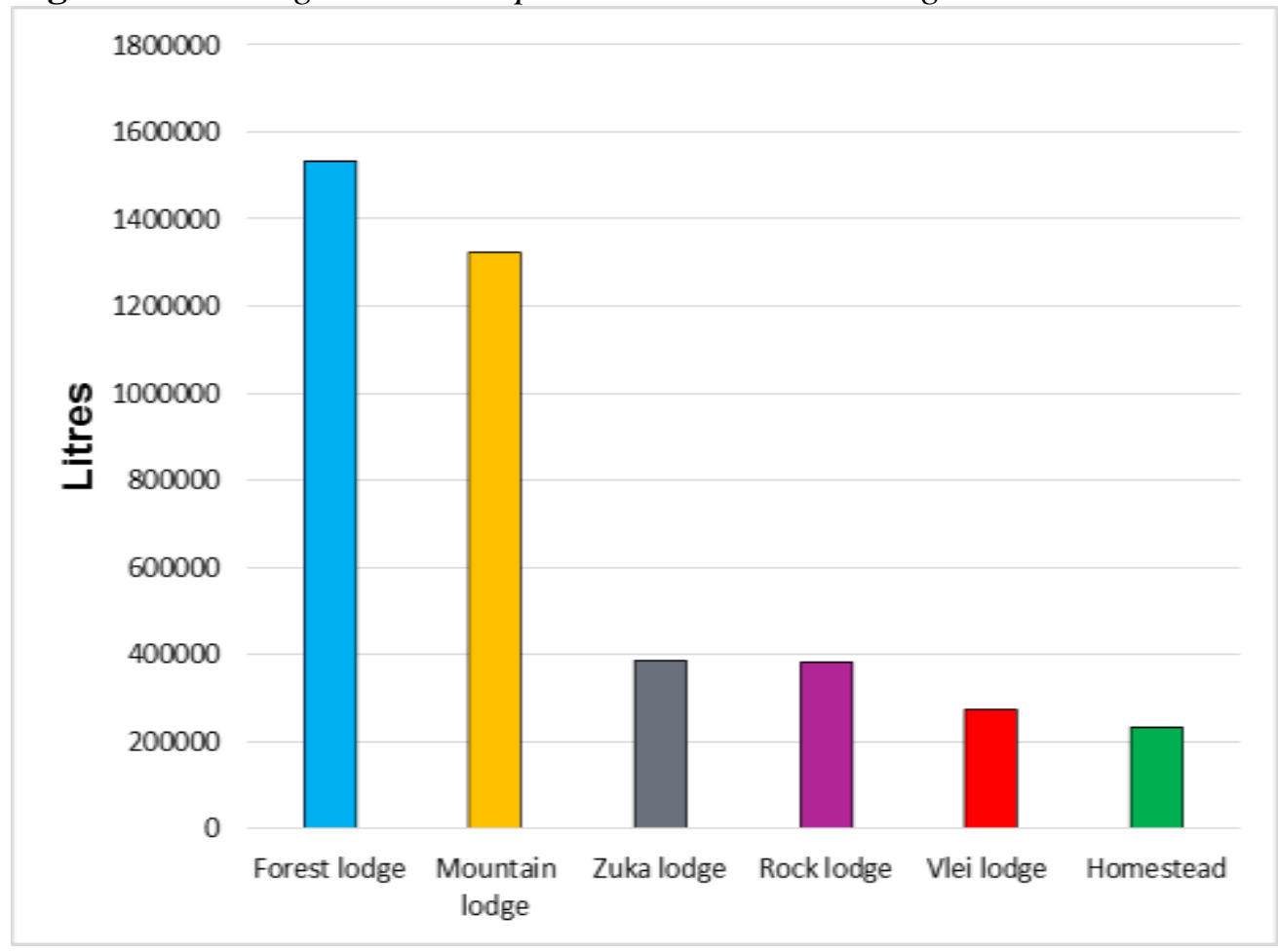

\section{Rainwater harvesting}

Only Forest Lodge had sufficient roofing to implement rainwater harvesting as all the other lodges had thatched roofs. The total area of roofing was measured and the following formula was applied to calculate the maximum volume of water that can be harvested from rain:

Area $\mathrm{x}$ rainfall $\mathrm{x} 0.9=$ Rainwater harvested 
The annual rainfall figures from 2012 (874mm), $2013(492 \mathrm{~mm})$ and 2014 $(462 \mathrm{~mm})$ were used during the calculation. Forest Lodge had a total area of 3 $419 \mathrm{~m}^{2}$ of roofing suitable for rain harvesting. Table 1 indicates the maximum volume of water that could have been harvested during 2012, 2013, and 2014 from the different harvesting locations at Forest Lodge.

Table 1. Potential Volume of Rainwater that could have been Harvested at Forest Lodge

\begin{tabular}{|c|c|c|c|c|}
\hline & $\begin{array}{c}\text { Area in } \\
\mathbf{~}^{\mathbf{2}}\end{array}$ & $\begin{array}{c}\text { Rainfall } \\
\text { harvesting } \\
\text { potential for 2012 }\end{array}$ & $\begin{array}{c}\text { Rainfall harvesting } \\
\text { potential for 2013 }\end{array}$ & $\begin{array}{c}\text { Rainfall harvesting } \\
\text { potential for 2014 }\end{array}$ \\
\hline Total & 3,419 & $\begin{array}{c}2,689 \mathrm{~m}^{\mathbf{3}} / \\
2,689,000 \text { litres }\end{array}$ & $1,514 \mathrm{~m}^{\mathbf{3}} /$ & $1,422 \mathrm{~m}^{\mathbf{3}} /$ \\
& & $1,514,000$ litres & $1,422,000$ litres \\
\hline
\end{tabular}

The results indicate that 2,689,000 litres of water could have been harvested from rain at Forest Lodge during 2012. Since then rainfall at Phinda has decreased by nearly half in 2013 and 2014 with only $492 \mathrm{~mm}$ and $462 \mathrm{~mm}$, well below the $874 \mathrm{~mm}$ from 2012 (19 year average of $777 \mathrm{~mm}$ per annum). Figure 13 illustrates the volume of water that could have been harvested on a monthly basis in 2014 compared against the monthly water usage from the three lodges in the northern section of Phinda. The results indicate that during the rainy season of 2014, rainwater could have nearly sustained one of the smaller lodges (Homestead / Vlei Lodge) for the entire rainy season (Jan - Mar and Oct - Dec).

Figure 13. Potential Rainwater Harvested Compared Aagainst the Water Usage of the Three Lodges in the Northern Section on a Monthly Base for 2014

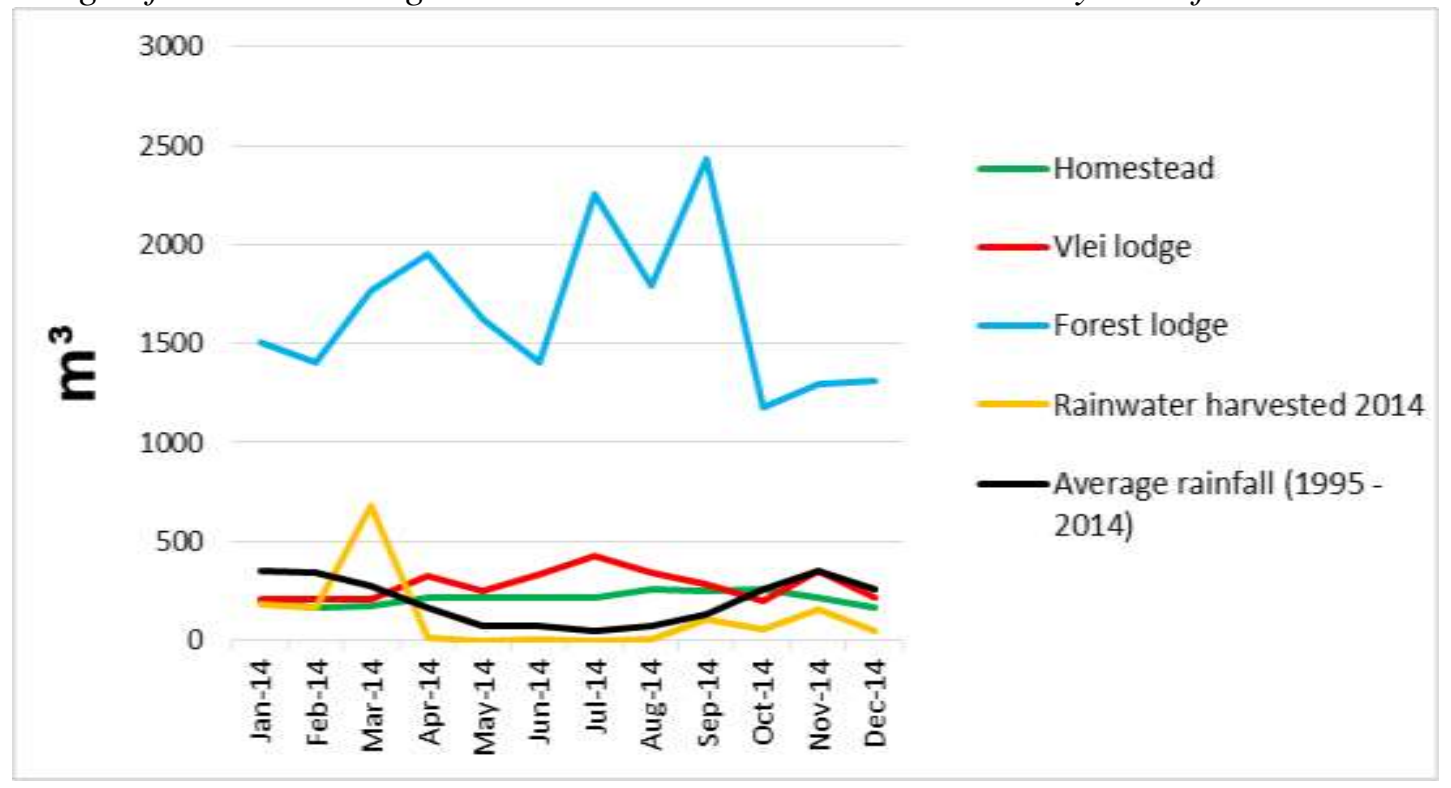




\section{Recommendations}

- Current water sources: Both the northern and southern section of Phinda is reliant on only one water source. It is highly advisable that more sources are identified as a backup supply should water at these primary sources become unavailable. Since this study only dealt with identifying the current sources, further investigation regarding recycling of water and purification of borehole water is necessary to ensure that operations at the lodges do not cease due to lack of water.

- Financial value of water: Water at Phinda is extremely valuable. It is therefore recommended that management consider some sort of recycling system such as reverse osmosis. Reverse osmosis is a sufficient way to purify grey water and could even with the correct filters purify salty borehole water. This will ensure that a backup water supply is available and will result in less abstraction and dependency from its current sources. The closure of lodges will result in the loss of millions of Rands in a very short period of time. As this study only identified the value of water, further investigation is required to compare cost of other infrastructure to recycle water against the current value of water.

- Water quantity: Staff distribution plays a major role in water consumption at the lodges and effects the figures severely. As this study only focussed on water usage per capita from the six lodges compared to the International Tourism Partnership standard, further investigation regarding staff villages such as Sondela, Swillies and Izwe are required.

- Rainwater harvesting: Due to the volume and financial value of rainwater, it is highly recommend that Phinda invest in harvesting rainwater as an alternative resource. Combined with a water recycling system, rainwater can contribute vastly towards water supply in the northern section, especially towards the two smaller lodges, Homestead and Vlei Lodge.

\section{Conclusion}

Phinda is completely dependent on water and the lack thereof would literally cost them millions of Rands. The current supply of water at Phinda can be divided into a southern and a northern section. The southern section source their water from the Hluhluwe water scheme through a municipal pipeline. This ensures a more stable supply and the risk of running out of water is much lower than that of the other lodges in the northern section. The northern section Lodges source their water from the Mkuze River.

The financial value of water in the northern section ranged between R4.31 and R7.16 per litre, making water extremely valuable for Phinda. Without water the lodges would be forced to cease operations and financial losses could escalate into the millions in a very shorts space of time.

Determining water quantity at Phinda became a complex process due to the distribution of staff. When staff were included in the calculations the 
average water consumption per person per night seemed constant ranging from $391 \mathrm{l} / \mathrm{p} / \mathrm{n}$ at Zuka Lodge to $684 \mathrm{l} / \mathrm{p} / \mathrm{n}$ at Vlei Lodge. The exception was Rock Lodge who showed an average consumption of 1,269 1/p/n, almost more than double than the second highest user per capita, Vlei Lodge. However when staff was taken out of the equation a different picture emerged and Zuka Lodge earned the title of the highest consumer per capita with $2,623 \mathrm{l} / \mathrm{p} / \mathrm{n}$. This emphasised the fact that staff and staff distribution plays a major role in water consumption per capita and that the figures including staff can be misleading.

Rainwater harvesting can only be implemented at Forest Lodge as none of the other lodges have sufficient roofing to serve as a catchment area. Vlei Lodge or Homestead would benefit from rainwater as rainwater harvesting can nearly sustain one of these lodges for a split period of six months during the rainy season.

\section{References}

\&Beyond. 2011. \&Beyond's groundbreaking Phinda land deal with communities, media release. May 2011. \&Beyond. Johannesburg.

\&Beyond. 2012. \&Beyond company profile. \&Beyond. Johannesburg.

Baker, M. \& Mearns, K. 2015. Sustainable tourism indicators to manage scarce water resources. The Responsible and Sustainable Tourism Handbook. Southern and East Africa. 13, 51-57.

Baoying, N. and Yuanqing, H. 2007. Tourism Development and Water Pollution: Case Study in Lijiang Ancient Town. China Population, Resource and Environment. 17(5). 123-127.

Becken, S. 2014. Water equity - Contrasting tourism water use with that of the local community. Water resources and industry. 7. 9-22.

Bushscapes. 2015. Phinda forest lodge. Available from http://www.bushscapes.co.za/ kwazulu-natal/phinda/phinda-forest-lodge/ [accessed 28 May 2016].

Gössling, S., Peeters, P., Hall, C.M., Ceron, J.P., Dubois, G., Lehmann, L.V. and Scot, D. 2012. Tourism and Water use: Supply, Demand and Security. An International Review. Tourism Management. 33, 1-15.

Gössling, S. 2001. The consequences of tourism for sustainable water use on a tropical island: Zanzibar, Tanzania. Journal of Environmental Management. 61, 179-191.

International Tourism Partnership (ITP) 2008. Environmental management for hotels: The industry guide to sustainable operation. (Third Edition) London: ITP.

Kinkade-Levario, H. 2007. Design for water: Rainwater harvesting, stormwater catchment and alternate water reuse. New Society Publishers. Gabriola Island.

Mwenga Kahinda, J. and Taigbenu, A.E. (2011). Rainwater harvesting in South Africa: Opportunities and Challenges. Physics and Chemistry of the Earth. 36, 968-976.

Owen-Smith, N., Kerley, G.I.H., Page, B., Slotow, R. and van Aarde, R.J. 2006. A scientific perspective on the management of elephants in the Kruger National Park and elsewhere. South African Journal of Science. 102. 389 - 394.

www.google.co.za/maps [accessed 17 May 2016]. 